\author{
AZ80과 TAZ711 마그네슘 압출재의 상온 및 고온 인장 특성과 \\ 고주기 피로 특성 \\ 이상원 · 김상훈 · 박성혁 * \\ 경북대학교 신소재공학부
}

\title{
Tensile Properties at Room and Elevated Temperatures and High-Cycle Fatigue Properties of Extruded AZ80 and TAZ711 Alloys
}

\author{
Sang Won Lee, Sang-Hoon Kim, and Sung Hyuk Park* \\ School of Materials Science and Engineering, Kyungpook National University, Daegu 41566, Republic of Korea
}

\begin{abstract}
The microstructure, tensile properties at room and elevated temperatures, and high-cycle fatigue behavior of an extruded Mg-7Sn-1Al-1Zn (TAZ711) alloy were investigated in comparison with those of an Mg-8Al-0.5Zn (AZ80) alloy extruded under the same conditions. The extruded AZ80 alloy exhibited a fully recrystallized structure, whereas the extruded TAZ711 alloy had a bimodal structure consisting of coarse nonrecrystallized grains and fine recrystallized grains. The TAZ711 alloy had smaller recrystallized grains and a larger amount of fine dynamic precipitates than the AZ80 alloy. Both alloys showed the typical texture of extruded Mg alloys in which the basal planes of the grains are arranged parallel to the extrusion direction, but the texture intensity of the TAZ711 alloy was greater than that of the AZ80 alloy. The yield strength of the TAZ711 alloy was higher than that of the AZ80 alloy at room temperature because of the finer grain size, stronger texture intensity, and greater amount of fine precipitates in the TAZ711 alloy. However, at an elevated temperature of $150^{\circ} \mathrm{C}$, the yield strength of the TAZ711 alloy was lower than that of the AZ80 alloy because the climb-controlled dislocation creep, grain boundary sliding, and diffusional creep behaviors were more easily generated in the TAZ711 alloy owing to its finer grain structure. As the applied tensile strain rate was reduced, the decrease in the strength of the TAZ711 alloy was greater than that of the AZ80 alloy owing to the higher strain rate sensitivity of the former alloy. Although the yield strength of the TAZ711 alloy at room temperature was higher than that of the AZ80 alloy, the TAZ711 alloy exhibited lower high-cycle fatigue resistance, which can be attributed to the occurrence of fatigue cracks at the twins formed in the coarse non-recrystallized grains remaining in the TAZ711 alloy.
\end{abstract}

(Received May 31, 2018; Accepted August 20, 2018)

Keywords: magnesium alloy, extrusion, microstructure, tensile properties, fatigue resistance

\section{1. 서 론}

최근 수송기기 산업에서 연비 효율 향상과 이산화탄소 배출 저감을 위해 수송기기 부품의 경량화에 주목하고 있 으며, 낮은 밀도와 높은 비강도를 가지는 마그네슘합금은 이에 적합한 소재로 알려져 있다 [1-4]. 마그네슘합금은 주 로 주조재로 수송기기 부품에 적용되어 왔지만, 마그네슘

*Corresponding Author: Sung Hyuk Park

[Tel: +82-53-950-5565, E-mail: sh.park@knu.ac.kr]

Copyright (C) The Korean Institute of Metals and Materials
가공재는 주조재보다 우수한 기계적 물성을 나타내기 때문 에 자동차의 인테리어(interior) 뿐만 아니라 바디(body)와 새시(chassis)와 같은 다양한 종류의 부품으로 적용될 수 있는 잠재력을 지니고 있다 [5-8]. 마그네슘 압출에 있어서 압출속도는 소재의 생산력과 밀접한 관련이 있으며, 이는 제품의 최종단가에 영향을 미칠 수 있다. 그러므로, 마그네 슘 부품의 가격경쟁력을 향상시키기 위해서는 높은 압출속 도가 요구된다. 하지만, 현재 가공재로 주로 상용되는 고강 도 $\mathrm{AZ} 80(\mathrm{Mg}-8 \mathrm{Al}-0.5 \mathrm{Zn}, \mathrm{wt} \%), \mathrm{ZK} 60(\mathrm{Mg}-6 \mathrm{Zn}-0.5 \mathrm{Zr}$, $\mathrm{wt} \%)$ 합금들은 알루미늄합금에 비해 낮은 최대 압출속도 
를 가지고 있으며, 이것은 수송기기 부품으로의 적용에 대 한 제한적 요소가 된다. 이렇게 상용 마그네슘합금들이 낮 은 최대 압출속도를 나타내는 것은 압출속도의 증가에 따 른 상당히 큰 가공 발열이 소재의 온도를 상승시키기 때문 이며, $\mathrm{Mg}-\mathrm{Al}$ 계, $\mathrm{Mg}-\mathrm{Zn}$ 계의 상용 마그네슘합금에서 형성 되는 $\mathrm{Mg}_{17} \mathrm{Al}_{12}, \mathrm{MgZn}_{2}$ 이차상 입자(second phase particle)들은 낮은 녹는점으로 인해 높은 압출속도로 야 기되는 소재의 온도 상승 시 용융이 일어나 표면에 열간 균열(hot cracking)을 발생시킨다 [7,9,10]. 그러므로, 이러 한 상용 마그네슘합금을 이용한 압출재 부품 생산에는 생 산성 저하에 따른 최종단가 상승이라는 문제점이 수반된다. 이러한 상용 마그네슘합금에서 낮은 녹는점을 가지는 기존 의 이차상 대신 열적으로 안정한 이차상을 형성하는 합금 을 개발하기 위한 연구가 활발히 진행되어 왔다 [11-17]. 그 중, $\mathrm{Mg}-\mathrm{Sn}$ 계 마그네슘합금은 $770{ }^{\circ} \mathrm{C}$ 의 상당히 높은 녹 는점을 가지고 있는 이차상인 $\mathrm{Mg}_{2} \mathrm{Sn}$ 을 형성하기 때문에 압출속도의 증가에 따른 이차상의 용융이 쉽게 발생하지 않는다는 특징이 있다 [18,19]. 최근 연구에 따르면, $\mathrm{Mg}$ $\mathrm{Sn}$ 계 마그네슘합금인 TAZ711(Mg-7Sn-1Al-1Zn, wt\%)합 금으로 $27 \mathrm{~m} / \mathrm{min}$ 의 높은 압출속도에서도 표면의 열간균 열이 없는 건전한 압출재 제조가 가능하며[20], $450{ }^{\circ} \mathrm{C}$ 의 높은 온도에서도 표면결함이 전혀 관찰되지 않았다고 보고 되고 있다 [21]. 이렇게 TAZ711 마그네슘합금은 압출 가 능한 압출조건 범위가 아주 넓기 때문에 기존의 상용 마그 네슘합금에 비해 제품생산성이 상당히 우수하다고 할 수 있다. 이와 같이 우수한 압출성을 나타내는 TAZ711 마그 네슘합금은 상용 AZ80 마그네슘합금과 비슷한 합금첨가량 에도 불구하고(TAZ711 합금은 총 $9 \mathrm{wt} \%, \mathrm{AZ} 80$ 합금은 총 $8.5 \mathrm{wt} \%$ ), 미세한 $\mathrm{Mg}_{2} \mathrm{Sn}$ 동적 석출물의 형성이 결정 립 미세화를 야기시켜 보다 더 향상된 인장항복강도(tensile yield strength)를 나타낸다고 보고되고 있다 [21,22].

한편, 자동차의 운행 중 엔진(engine)과 트랜스미션 (transmission)에서 발생하는 과열로 인해 트랜스미션 케이 스(transmission case), 엔진블록(engine block)과 같은 파 워트레인(powertrain)의 온도는 $200{ }^{\circ} \mathrm{C}$ 이상으로 상승하게 된다 [8,23]. 형상이 복잡한 파워트레인에는 마그네슘 압출 재의 적용이 제한적일 수 있지만, 파워트레인을 지지하는 새시로 적용되는 마그네슘 압출재 부품들은 파워트레인에 서 발생한 상당한 열의 전달로 인해 온도가 상승하여 물성 이 저하될 수 있다. 게다가, 마그네슘 압출재 부품은 주행 중 엔진의 진동과 지면과의 마찰로 인해 반복적인 응력이 나 변형이 발생하여 불가피하게 치명적인 피로 파괴를 일 으킬 수 있다. 그러므로, 마그네슘 압출재가 자동차 부품으
로 적용되기 위해서는 작동환경에 따른 기계적 물성과 피 로 특성이 평가되어야 하며 고온 변형거동과 피로거동에 대한 연구가 절실히 요구된다. 하지만, TAZ711 마그네슘 합금이 상용 AZ80 마그네슘합금에 비해 우수한 압출성과 높은 강도를 지님에도 불구하고, 아직까지 고온 물성과 피 로 특성에 대한 연구는 미비한 실정이다. 따라서, 본 연구 에서는 동일한 압출 조건에서 압출된 AZ80과 TAZ711 마 그네슘 압출재의 미세조직을 비교 분석하고, 그에 따른 두 압출재의 상온 및 고온 인장 특성과 고주기 피로 특성에 대해 조사하였다.

\section{2. 실험 방법}

본 연구에서는 AZ80과 TAZ711 합금을 사용하였다. 압 출을 위한 빌렛(billet)을 제조하기 위해, 도가니에 순수 마 그네슘을 장입하고 $720^{\circ} \mathrm{C}$ 에서 용해 시킨 후 $\mathrm{Al}, \mathrm{Sn}, \mathrm{Zn}$ 의 합금원소를 첨가하여 20 분 동안 유지하였고, 용해 중 용탕의 산화를 방지하기 위해 $\mathrm{CO}_{2}$ 와 $\mathrm{SF}_{6}$ 혼합 가스를 주 입하였다. 안정화된 용탕을 $210^{\circ} \mathrm{C}$ 로 예열된 스틸몰드(steel mold)에 출탕하여 압출 빌렛을 제조하였다. 제조된 빌렛의 균질화 열처리는 PANDAT 소프트웨어를 통해 얻어진 평 형 상태도에서의 용융 온도를 고려하여 AZ80 합금은 $400{ }^{\circ} \mathrm{C}, \quad \mathrm{TAZ} 711$ 합금은 $500{ }^{\circ} \mathrm{C}$ 에서 24 시간 동안 진행하 였으며, 열처리 후 과포화 상태를 만들기 위해 수냉하였다. 압출을 위해, 균질화 처리된 빌렛을 직경 $80 \mathrm{~mm}$ 로 가공 후 $250{ }^{\circ} \mathrm{C}$ 의 온도에서 1 시간 동안 예열하고, $500 \mathrm{ton}$ 의 용 량을 가지는 직간접 겸용 압출기를 이용하여 $1 \mathrm{~mm} / \mathrm{s}$ 의 램 속도(ram speed)로 $250{ }^{\circ} \mathrm{C}$ 에서 25:1의 압출비(extrusion ratio)로 간접압출(indirect extrusion)을 실시하였다.

압출재의 미세조직과 집합조직을 관찰하기 위해 압출재 의 길이방향 단면(logitudinal cross-section)을 광학현미경 (optical microscope)과 전자 후방 산란 회절 기법(electron backscatter diffraction, $\mathrm{EBSD})$ 을 이용하여 측정하였다. 압 출재의 기계적 특성을 평가 비교하기 위해 상온 및 고온 인장 시험과 고주기 피로 시험을 시행하였다. 인장 시험편 은 미국재료시험협회(American Society for Testing and Materials, ASTM) E8/E8M 규격을 따라 그림 1(a)와 (b) 와 같이 제작하였으며, 상온 인장 시험은 Instron 4206 시 험기를 이용하여 $5 \times 10^{-3} \mathrm{~s}^{-1}$ 의 변형률 속도로 상온에서 수 행하였으며, 고온 인장시험은 Instron 5581 시험기를 이용 하여 $150{ }^{\circ} \mathrm{C}$ 의 온도에서 $10^{-3}$ 와 $10^{-4} \mathrm{~s}^{-1}$ 의 변형률 속도에 서 각각 수행하였다. 고주기 피로 시험편은 그림 1(c)와 같이 시험편의 중심 부분이 가장 작은 직경을 가지는 
(a)

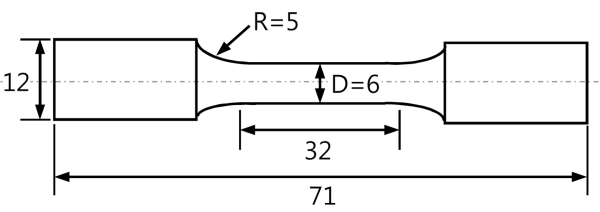

(b)

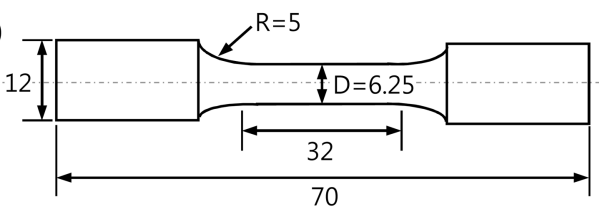

(c)

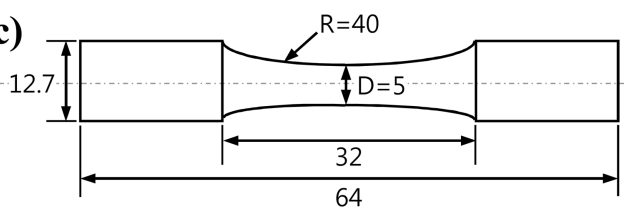

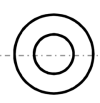
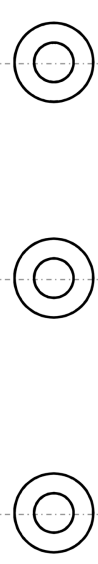

Fig. 1. Dimensions of samples for (a) room- and (b) elevatedtemperature tensile testing and (c) high-cycle fatigue testing.

ASTM E466의 continuous radius between ends 타입으로 제작하였다. 피로 시험은 Instron 8801을 이용하여 상온에 서 응력제어 방식(stress controlled mode)으로 사인파(sine wave)로 응력비(stress ratio) -1조건에서 $10 \mathrm{~Hz}$ 의 진동수로 1축 인장-압축 피로 시험을 수행하였다. 피로 균열 시작점 확인을 위해 피로 시험 후 파단된 시편을 주사전자현미경 (scanning electron microscope, SEM)을 이용하여 파면을 관찰하였다.

\section{3. 결과 및 고찰}

\section{1. 압출 하중 변화 및 미세조직}

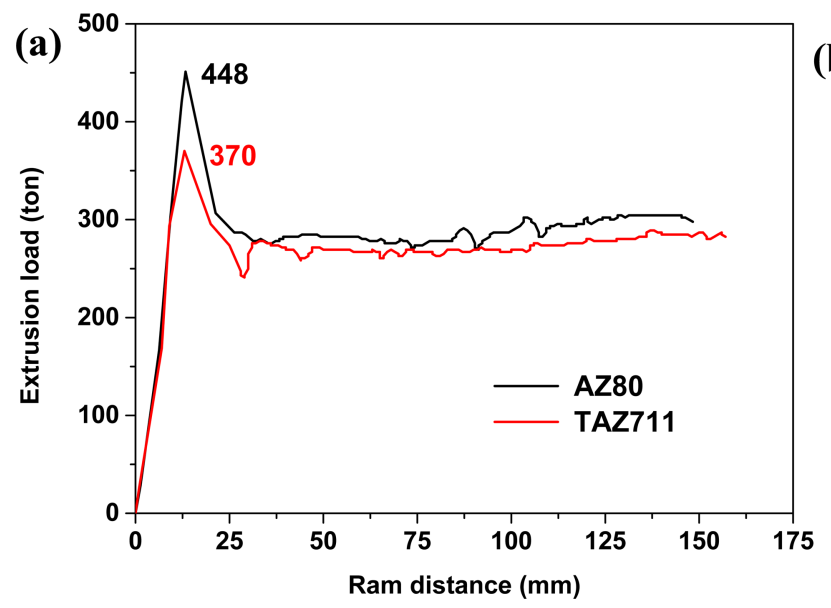

(b)

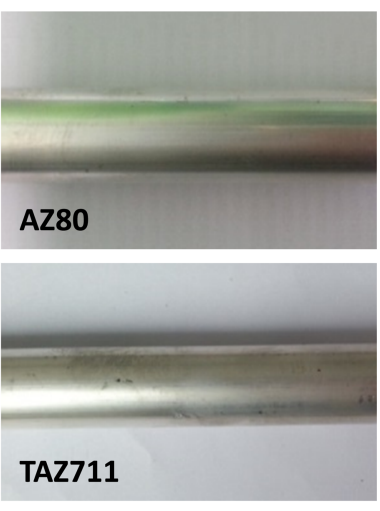

Fig. 2. (a) Variation in extruded load during indirect extrusion and (b) extruded bar images. 

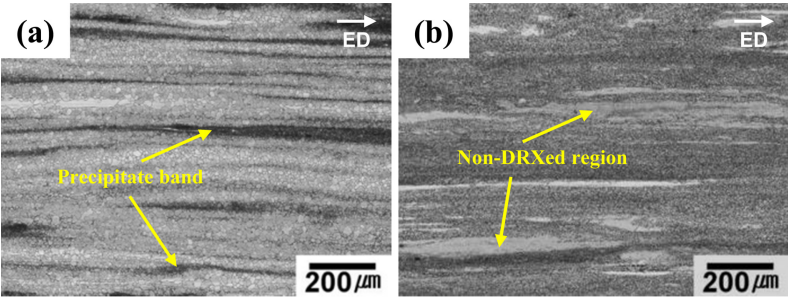

(c)

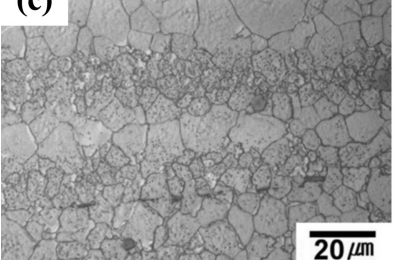

(d)

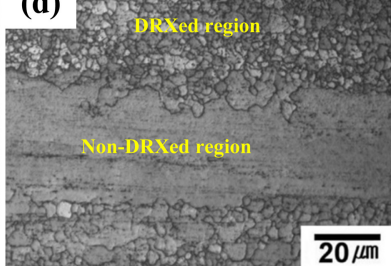

Fig. 3. Optical micrographs at (a, b) low and (c, d) high magnifications of extruded (a, c) AZ80 and (b, d) TAZ711 alloys. DRXed and non-DRXed regions denote the dynamically recrystallized and non-dynamically recrystallized regions, respectively.

(precipitate band)가 관찰되며(그림 3(a)), 석출 밴드 영역 에서는 다른 영역에 비해 결정립이 미세한 것을 알 수 있
다(그림 3(c)). 이는 압출 중 형성된 동적 석출물들이 재결 정된 결정립의 입계 움직임을 방해하여 결정립의 성장을 억제시킴으로써 비교적 미세한 결정립을 가지게 되는 것이 다 [15]. 이와 같이 AZ80 합금의 경우 동적 석출물들이 석출 밴드에 국부적으로 형성되어 재결정된 결정립들의 크 기 편차가 큰 반면, TAZ711 합금에서는 석출물들이 재결 정된 영역 전반에 걸쳐 골고루 분포하여 균일한 결정립 크 기를 가지고 있다(그림 3(d)). 또한, TAZ711 합금에 조대 한 미재결정된 결정립이 존재하지만, 재결정된 결정립의 크 기는 TAZ711 합금이 AZ80 합금 보다 훨씬 미세하다(그 림 3(c), (d)). 이러한 결과를 통해, TAZ711 합금이 $\mathrm{AZ80}$ 합금에 비해 압출 중 동적 재결정 거동의 활성화가 약하게 발생하여 완전 재결정 조직을 가지지 못하지만, 동 적 석출 거동이 소재 전반에 걸쳐 균일하게 발생하여 미세 한 재결정된 결정립들이 형성된다는 것을 알 수 있다.

\section{2. 재결정 결정립 크기 및 집합조직}

그림 4는 압출재의 $\mathrm{EBSD}$ 분석 결과로서, 압출재의 미 세조직을 보다 명확히 보여주는 역 극점도 지도(inverse
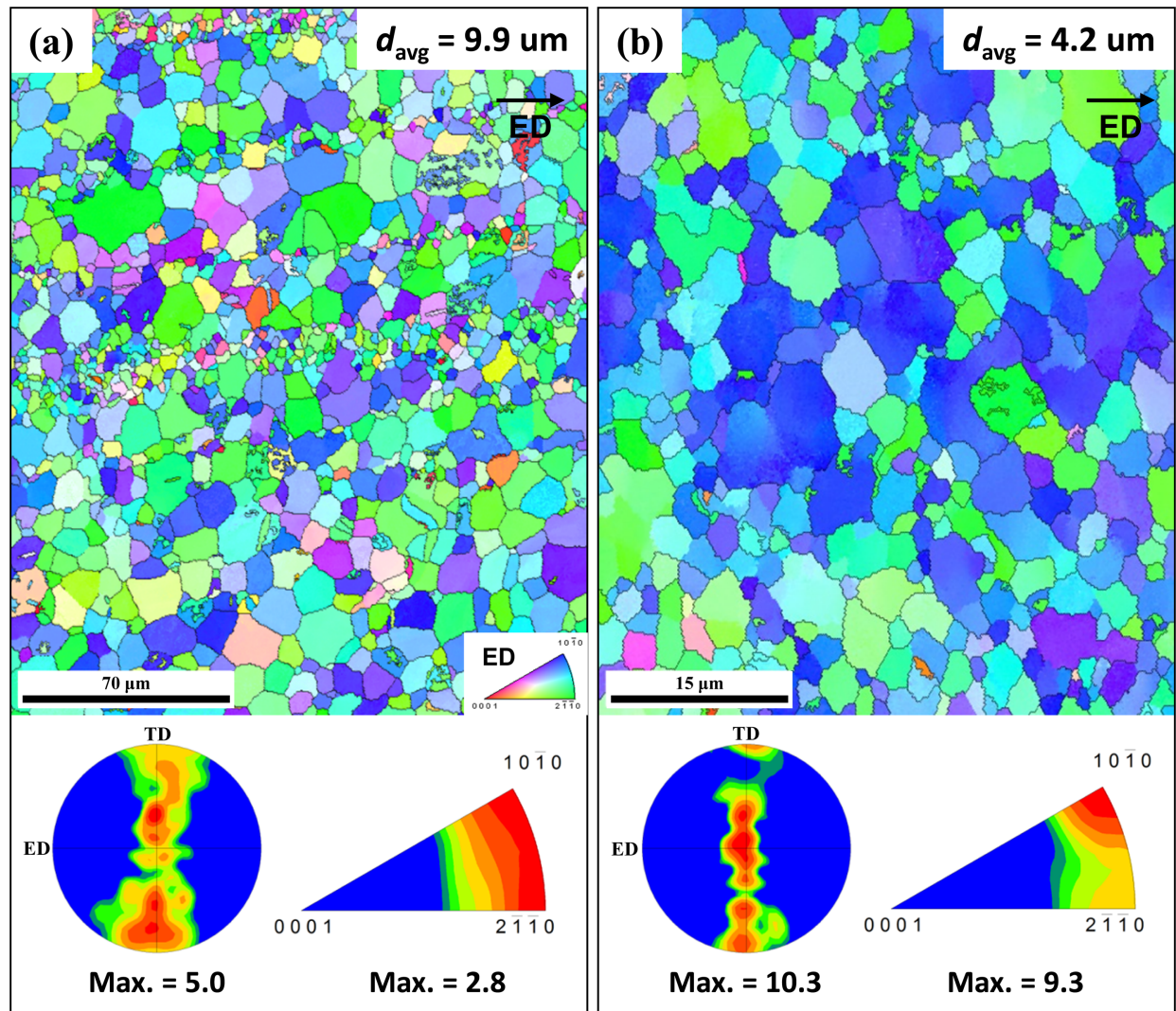

Fig. 4. ED inverse pole figure maps and (0001) pole figures and ED inverse pole figures of extruded (a) AZ80 and (b) TAZ711 alloy. $d_{\text {avg }}$ denotes the average grain size. 
pole figure map)과 함께 집합조직을 보여주는 (0001) 극 점도(pole figure) 및 $\mathrm{ED}$ 역 극점도를 나타내었다. AZ80 합금에서는 미세한 결정립들이 띠를 이루며 압출 방향과 평행하게 배열되어 재결정된 결정립들의 크기 편차가 존재 하지만 (그림 4(a)), TAZ711 합금에서는 재결정된 결정립 들이 비교적 균일한 크기를 가지고 있다(그림 4(b)). AZ80 합금의 재결정된 결정립의 평균 크기는 $9.9 \mu \mathrm{m}$ 로 TAZ711 합금의 $4.2 \mu \mathrm{m}$ 에 비해 약 2.4 배 조대하다. 따라서, 압출 재의 전체적인 미세조직 상태를 본다면, 완전 재결정이 발 생한 AZ80 합금이 불완전한 재결정으로 인해 조대한 미 재결정된 결정립들이 존재하는 TAZ711 합금에 비해 조직 균일도가 우수하지만, 재결정된 영역만 고려한다면 TAZ711 합금이 AZ80 합금에 비해 결정립이 균일하고 미세하다. 극점도를 보면 두 합금 모두 결정립들의 기저극(basal pole)이 압출 방향과 수직으로 배열되어 있는 전형적인 마 그네슘 압출재의 집합조직을 가지고 있으나, 최대 집합조 직 강도(maximum texture intensity)는 TAZ711 합금이 AZ80 합금에 비해 2배 가량 크다. 또한, TAZ711 합금에 서의 기저극의 분포가 AZ80 합금에 비해 TD 선에 더 가 깝게 분포하고 있다. 이는 압출 방향으로의 인장 시험 시 TAZ711 합금에서의 기저면 슬립 활성화가 AZ80 합금에 비해 더욱 어려워져 집합조직 강화 효과가 더 크게 발생한 다는 것을 의미한다. 게다가, TAZ711 합금은 기저극 뿐만 아니라 각주형 극 또한 방향성을 가지고 있다. 역극점도를 보면 AZ80 합금의 경우 <10-10>에서 <2-1-10> 방위까 지 고른 분포를 가지고 있는 반면, TAZ711 합금은 <10$10>$ 방위에 높은 강도를 가지고 있다. 따라서, TAZ711 합금은 기저극이 압출 방향과 수직하며, 각주형 극 중 하 나가 압출 방향과 평행하게 배열된 강한 집합조직을 가짐을 알 수 있다.

\section{3. 상온 인장 특성}

그림 5 는 압출재의 상온 인장 곡선을 나타낸 것으로, TAZ711 합금의 항복강도(yield stength, YS)가 $247 \mathrm{MPa}$ 로 AZ80 합금의 $192 \mathrm{Mpa}$ 에 비해 29\% 높다. 하지만, 최대인장강도(ultimate tensile strength, UTS)는 TAZ711

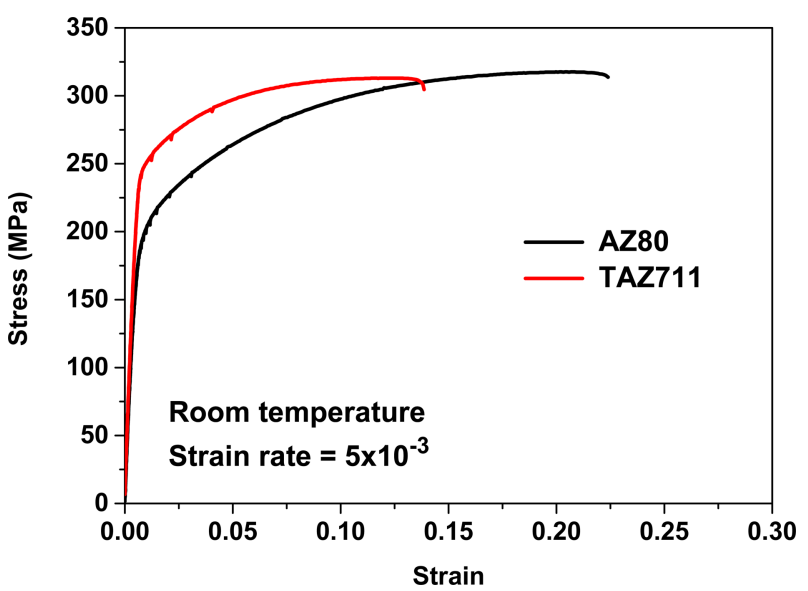

Fig. 5. Room temperature tensile stress-strain curves of extruded AZ80 and TAZ711 alloys.

합금이 $312 \mathrm{MPa}, \mathrm{AZ} 80$ 합금이 $317 \mathrm{MPa}$ 로 큰 차이를 보 이지 않았으며, 연신율(elongation, EL)은 AZ80 합금이 $22.2 \%$ 로 TAZ711 합금의 $11.9 \%$ 에 비해 $87 \%$ 높다 (표 1). TAZ711 합금의 높은 항복강도는 결정립 미세화가 주 된 요인으로 판단된다. 조대한 미재결정된 결정립들이 일 부 존재하지만 재결정된 결정립의 크기가 AZ80 합금에 비 해 매우 미세하기 때문에 인장 변형 시 결정립계 강화 (grain-boundary strengthening) 효과가 더 크게 발생하게 될 것이다. 또한, TAZ711 합금의 강한 집합조직으로 인해 상온 인장 변형 시 주된 슬립기구인 기저면 슬립(basal slip)의 활성화가 억제되고, 이로 인해 야기되는 집합조직 강화(texture strengthening) 효과도 일부 기여할 것으로 판 단된다. 더불어, TAZ711합금에서는 석출물 또한 균일하게 분포하고 있어 집합체 형태의 석출물 밴드로 형성된 AZ80 합금에 비해 입자간 평균 거리(average interparticle spacing)가 크게 작아, 인장 변형 시 전위들의 이동을 효율 적으로 방해함으로써 더욱 강화된 석출 강화(precipitate strengthening) 효과를 야기시킬 것이다. TAZ711 합금의 항복강도가 AZ80 합금에 비해 $55 \mathrm{MPa}$ 이 높음에도 불구 하고 최대인장강도는 AZ80 합금이 오히려 TAZ711 합금 보다 $5 \mathrm{MPa}$ 높으며, 이는 $\mathrm{AZ80}$ 합금의 가공경화능(strain

Table 1. Temperature tensile properties at room and elevated temperatures of extruded AZ80 and TAZ711 alloys.

\begin{tabular}{cccccccc}
\hline \multirow{2}{*}{$\begin{array}{c}\text { Temperature } \\
\left({ }^{\circ} \mathrm{C}\right)\end{array}$} & $\begin{array}{c}\text { Strain rate } \\
\left(\mathrm{s}^{-1}\right)\end{array}$ & YS $(\mathrm{MPa})$ & UTS $(\mathrm{MPa})$ & EL $(\%)$ & YS $(\mathrm{MPa})$ & UTS $(\mathrm{MPa})$ & EL $(\%)$ \\
\hline 25 & $5 \times 10^{-3}$ & 192 & 317 & 22.2 & 247 & 312 & 11.9 \\
\hline \multirow{2}{*}{150} & $10^{-3}$ & 149 & 188 & 40.7 & 139 & 150 & 47.4 \\
\cline { 2 - 8 } & $10^{-4}$ & 126 & 143 & 42.6 & 109 & 119 & 48.7 \\
\hline
\end{tabular}



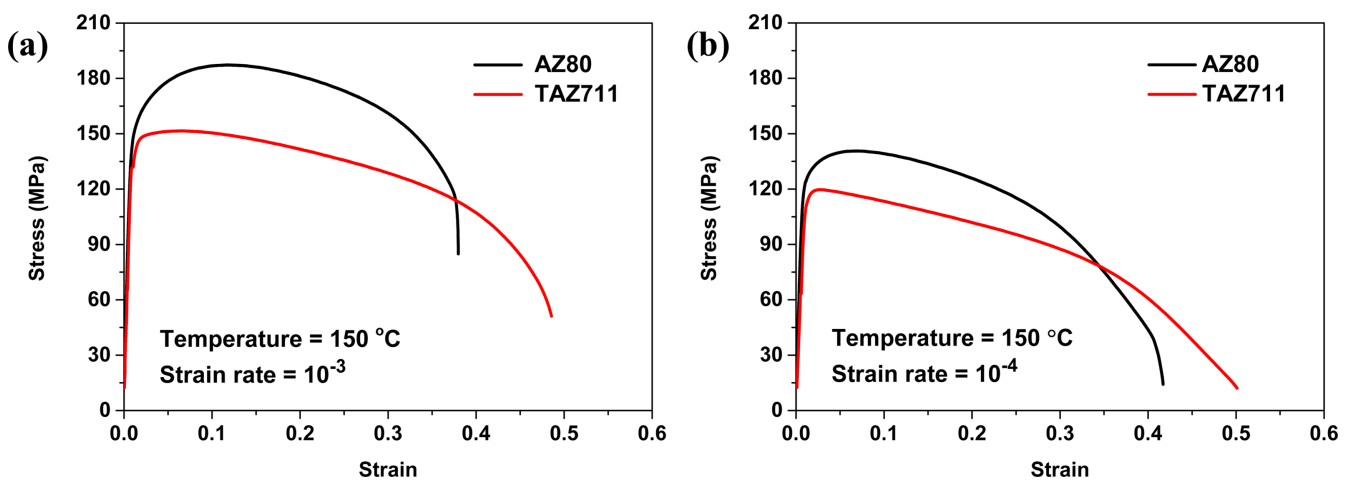

Fig. 6. Elevated temperature tensile stress-strain curves of extruded AZ80 and TAZ711 alloys at strain rates of (a) $10^{-3}$ and (b) $10^{-4}$.

hardening ability)이 TAZ711 합금보다 더 크기 때문이다. 그림 5에 보이는 바와 같이, AZ80 합금은 탄성 영역 이 후 소성변형에 의해 강도가 크게 증가하는 반면, TAZ711 합금은 항복강도는 비교적 높지만 소성변형에 의한 가공경 화는 크지 않아 최대인장강도가 AZ80 합금 보다 낮게 된 다. 이러한 가공경화의 차이는 형성되는 이차상의 차이로 인한 것으로 사료된다. TAZ711 합금은 열간 압출 중 $\mathrm{Mg}_{2} \mathrm{Sn}$ 상이 동적 석출되는 반면, $\mathrm{AZ80}$ 합금은 $\mathrm{Mg}_{17} \mathrm{Al}_{12}$ 상이 석출된다 [25,26]. $\mathrm{Mg}_{2} \mathrm{Sn}$ 은 면심입방(fcc) 구조를 가 지며, $\mathrm{Mg}_{17} \mathrm{Al}_{12}$ 는 체심입방 $(\mathrm{bcc})$ 구조를 가지고 있다 [27,28]. $\mathrm{Mg}_{2} \mathrm{Sn}$ 상은 $\mathrm{Fm} 3 \mathrm{~m}$ 의 공간군(space group)을 가 지며 하나의 단위포(unit cell)에 8개의 마그네슘 원자와 4 개의 주석 원자를 가진 비교적 단순한 구조를 이루고 있다 [27]. 반면, $\mathrm{I} 43 \mathrm{~m}$ 의 공간군을 가지는 $\mathrm{Mg}_{17} \mathrm{Al}_{12}$ 상은 하나 의 단위포에 34 개의 마그네슘 원자와 17 개의 알루미늄 원 자로 이루어진 매우 크고 복잡한 구조를 이루고 있다 [28]. 결정구조가 복잡해지면 뚜렷한 최조밀면(close-packed plane)과 최조밀방향(close-packed direction)을 가지지 못하 기 때문에 피어스 나바로 힘(Peierls-Nabarro force)이 증 가하게 되어 전위들의 움직임이 어렵게 된다 [24]. 따라서 $\mathrm{Mg}_{17} \mathrm{Al}_{12}$ 이차상을 가진 $\mathrm{AZ} 80$ 합금에서 전위가 석출물을 자르거나 통과하기 위해 더 높은 응력이 요구되고, 이로 인해 인장 변형 동안 가공경화가 더 크게 발생한 것으로 판단된다.

\section{4. 고온 인장 특성}

그림 6 은 다른 변형률 속도 조건으로 $150{ }^{\circ} \mathrm{C}$ 의 온도에서 인장 시험한 결과를 보여준다. 상온에서의 인장 결과에서 의 항복강도는 TAZ711 합금이 높고, 연신율은 AZ80 합 금이 높았다. 이와는 반대로, $1500^{\circ} \mathrm{C}$ 인장 결과에서는 AZ80 합금의 강도가 높고, TAZ711 합금의 연신율이 높게
나타난다. 이는 상온과 고온에서의 주된 변형기구(dominant deformation mechanism)의 차이에 의한 것으로 볼 수 있 다. 상온에서는 전위들의 이동에 의한 전위 슬립 (dislocation slip)이 주된 변형기구인 반면, 고온에서는 climb-control에 의한 전위 크리프(dislocation creep), 결정 립 계면에서의 미끄러짐(grain boundary sliding, GBS) 운 동, 확산에 의한 확산크리프(diffusional creep) 등에 의해 발생하는 것으로 알려져 있다 [24,29,30]. 일반적으로 금속 소재의 상온에서의 변형률 속도 민감도(strain rate sensitivity, $m$ )는 거의 0 에 가까운 매우 낮은 값을 가지는 것으로 알려져 있다 [24]. 따라서, 상온 변형에서는 변형률 속도 변화에 따른 강도 변화가 거의 발생하지 않는다. 하 지만 이러한 변형률 속도 민감도는 온도가 증가함에 따라 크게 증가하여 고온 변형 시에는 변형률 속도에 따른 강도 변화가 크게 발생하고 주 변형기구에 따라 다른 변형률 속 도 민감도를 나타낸다. 각 변형기구에 따른 변형률 속도 민감도는 climb-controlled 전위 크리프일 경우 $0.14 \sim 0.2$, $\mathrm{GBS}$ 일 경우 0.5 , 그리고 확산 크리프일 경우 1 에 가까운 값을 가진다고 알려져 있다 [30]. 이러한 변형률 속도 변 화에 따른 인장 물성 변화를 확인하기 위해 $10^{-3}$ 와 $10^{-4} \mathrm{~s}$ ${ }^{1}$ 의 변형률 속도에서 고온 인장 시험을 하였고, 그 결과 변형률 속도가 $10^{-3}$ 에서 $10^{-4} \mathrm{~s}^{-1}$ 로 감소함에 따라 AZ80과 TAZ711 합금의 항복강도는 각각 $23,30 \mathrm{MPa}$ 감소하였다 (그림 6과 표 1). 변형률 속도 감소로 인해 야기되는 항복 강도 저하는 TAZ711 합금에서는 $22 \%$ 로 AZ80 합금에서 의 $15 \%$ 보다 크게 나타났다(표 1). 항복강도와 변형률 속 도 민감도의 관계를 나타내는 $\sigma_{0}=C(\dot{\varepsilon})^{m}$ (여기서, $\sigma_{0}$ 는 항복강도, $C$ 는 상수, $\dot{\varepsilon}$ 은 변형률 속도, $m$ 은 변형률 속도 민감도이다) 식을 통해 구한 변형률 속도 민감도 $(m)$ 또한 TAZ711 합금이 0.11로 AZ80 합금의 0.07 보다 높다. 이 는 TAZ711 합금이 동일한 변형 온도 하에서 변형률 속도 


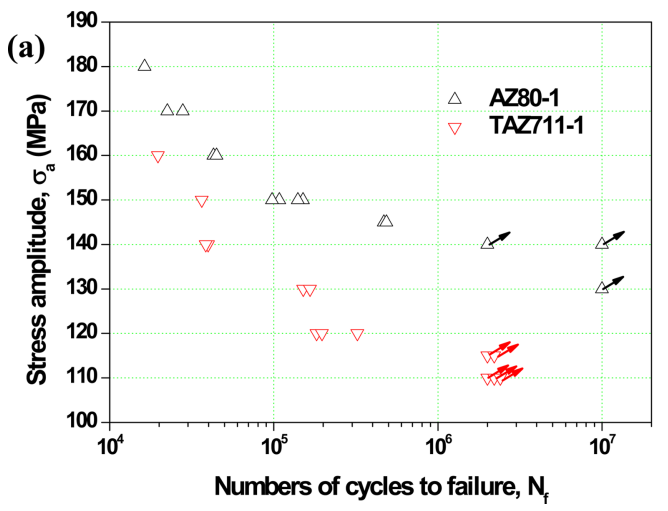

(b)

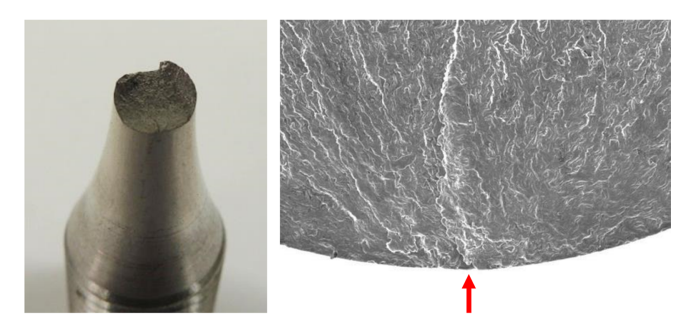

Fig. 7. (a) High-cycle fatigue test results (S-N curves) of extruded AZ80 and TAZ711 alloys and (b) sample image and SEM micrograph of fatigue fractured specimen at a stress amplitude of $150 \mathrm{MPa}$ of extruded AZ80 alloy.

변화에 따른 항복강도 변화가 AZ80 합금에 비해 크다는 것을 의미하며, 고온 변형 하에서 AZ80 합금에 비해 TAZ711 합금에서 전위 크리프가 더 활발하게 발생하여 변 형률 속도 변화에 더 민감한 것으로 판단된다. 또한 Koike 등[31]은 $\mathrm{AZ} 31$ 합금에서 $25 \sim 250^{\circ} \mathrm{C}$ 온도 범위에 서 $\mathrm{GBS}$ 이 발생하는 것을 관찰하였으며, 온도가 증가할수 록 $\mathrm{GBS}$ 의 영향이 커진다고 보고하였고, $\mathrm{GBS}$ 이 일어나는 결정립계의 양은 결정립 크기가 커질수록 감소하기 때문에 GBS를 위한 임계응력(threshold stress)은 결정립 크기에 비례하여 증가한다 [32]. 확산 크리프로 인한 크리프 속도 역시 고온일 경우 결정립 크기의 제곱에 반비례하고 저온 일 경우 결정립 크기의 세제곱에 반비례한다고 알려져 있 다 [24]. 따라서, GBS와 확산 크리프 또한 작은 결정립 크기를 가지는 TAZ711 합금에서 더 용이하게 발생되며, 이는 전위 크리프와 더불어 TAZ711 합금이 AZ80 합금에 비해 낮은 고온 강도를 가지게 하는 원인으로 판단된다.

\section{5. 고주기 피로 특성}

그림 7은 압출재의 1축 인장-압축 고주기 피로 시험 결 과를 나타낸 응력-수명(stress-life, S-N) 그래프이다. 전체 응력 구간에서 AZ80 합금이 TAZ711 합금 보다 긴 피로 수명(fatigue life)을 보이며, 피로한계(fatigue limit) 또한 $\mathrm{AZ80}$ 합금이 $140 \mathrm{MPa}$ 로 TAZ711 합금의 $115 \mathrm{MPa}$ 보다 약 $22 \%$ 높다. 그림 $7(\mathrm{~b})$ 에서 보이는 바와 같이, 두 합금 모두 가해진 응력에 상관없이 모두 시편이 표면에서 피로 균열(fatigue crack)이 발생하여 내부로 전파(propagation)하 여 피로 파괴(fatigue fracture)가 발생하였다. 항복 응력 보다 낮은 응력일지라도 반복적으로 부가되면 소재 내부에 전위의 이동이 발생하고 영구슬립밴드(persistent slip band, $\mathrm{PSB}$ )가 생성되어 소재 표면에 슬립띠 도출부(extrusion)와
슬립띠 골(intrusion)이 형성된다 [33]. 이러한 미세 표면 단차는 응력 집중(stress concentration)을 야기시켜 피로 균열을 발생시킨다. 따라서, 소재 내부에 응력 집중을 야기 하는 개재물(inclusion)과 기공(void) 등과 같은 3 차원 격자 결함(3-dimensional lattice defect)이 존재하지 않을 경우에 는 일반적으로 피로균열은 소재의 표면에서 발생하게 된다. 이러한 경우 소재의 항복강도가 높을수록 슬립 비가역성 (slip irrevesibility)이 향상되어 피로균열의 시작점이 되는 도출부, 골, 돌출부(protrusion)의 형성이 억제되어 피로 저 항성(fatigue resistance)이 향상된다. 그러나, 본 연구에서는 TAZ711 합금의 상온 항복강도 $(247 \mathrm{MPa})$ 가 AZ80 합금의 항복강도(192 MPa) 보다 크게 높음에도 불구하고, 피로 특 성은 AZ80 합금이 더 우수한 결과가 얻어졌다. 이러한 TAZ711 합금의 낮은 피로 저항성은 조대한 미재결정된 결 정립에서의 쌍정 형성에 의한 것으로 판단된다. 마그네슘 의 경우 육방정계 구조를 가지며 격자상수의 비(c/a ratio) 가 1.624 를 가지고 있어 기저면 슬립이 주된 슬립 기구가 되며, 각주형 슬립(prismatic slip), 피라미드형 슬립 (pyramidal slip)과 같은 비기저면 슬립 시스템(non-basal slip system)들의 상온에서의 임계분해전단응력(critical resolved shear stress, CRSS)이 기저면 슬립의 CRSS 보 다 훨씬 높아 상온에서의 독립적인 슬립 시스템의 수는 2 개 밖에 존재하지 않게 된다 [34,35]. 이러한 마그네슘 합 금에서의 제한된 슬립 시스템으로 인해 소성 변형 시 변형 을 수용하기 위해 쌍정(twinning)이 쉽게 발생하게 된다. 쌍정의 특징으로서 쌍정이 형성되면 쌍정밴드(twin band) 내에서의 결정학적 방위(crystallographic orientation)가 바 뀌는 격자회전(lattice rotation)이 발생하고, 이로 인해 쌍정 밴드에서의 슬립에 대한 활성화 정도도 변하게 된다 [36,37]. 기존 연구에 따르면, 마그네슘 가공재를 압연 또 
는 압출 방향으로 1축 인장-압축 고주기 피로 실험을 수행 할 경우, 반복 하중에 의해 소재 내에 변형쌍정 (deformation twin)이 형성되게 되고 쌍정밴드 영역의 방위 가 변하여 기저면 슬립의 활성이 용이하게 되기 때문에 전 위가 쌍정밴드 내에 집적하게 된다. 이로 인해 시편의 표면 근방에 형성된 쌍정에서 피로균열이 발생하는 것으로 보고 되었다 [38,39]. 이는 피로 시험 중에 소재 내에 쌍정이 형성될 경우 고주기 피로 특성이 저하된다는 것을 의미한 다. 또한, 쌍정 형성을 위해 필요한 활성화 응력(activation stress for twinning)은 결정립 크기에 매우 민감한 것으로 알려져 있다 [40,41]. 금속소재의 가장 주요한 2개의 변형 기구인 슬립과 쌍정은 모두 결정립이 미세해짐에 따라 활 성화 응력이 증가하지만, 마그네슘 합금에서는 결정립 크 기가 감소할 경우 쌍정의 활성화 응력이 슬립에 비해 더욱 크게 증가하게 된다 [41]. TAZ711 합금의 경우 AZ80 합 금과 달리 부분적인 동적 재결정으로 인해 매우 조대한 미 재결정된 결정립들이 존재하고 있다 (그림 3(b)). TAZ711 합금의 재결정된 결정립의 크기 $(4.2 \mu \mathrm{m})$ 가 AZ80 합금의 결정립 크기 $(9.9 \mu \mathrm{m})$ 보다 미세하지만, TAZ711 합금에는 길이 $100 \sim 500 \mu \mathrm{m}$, 폭 $20 \sim 100 \mu \mathrm{m}$ 을 가지는 조대한 결 정립들이 있어 반복 하중이 가해지는 피로 시험 동안 쉽게 쌍정이 형성될 것이다. 앞서 그림 4에서 언급한 바와 같이, 대부분의 결정립의 기저극이 압출 방향과 수직으로 배열되 어 있다. 그러므로, 압출 방향으로의 인장과 압축이 가해지 는 피로 시험 하에서 기저면 슬립에 대한 Schmid factor 가 매우 낮기 때문에 슬립이 잘 활성화 되지 않는다. 하지 만, 조대한 결정립에서 쌍정이 형성되면 쌍정된 영역은 격 자 회전으로 인해 기저면 슬립이 용이한 방위로 배열되어 쌍정밴드 내에 전위들이 쉽게 형성되고 축적되므로 피로 균열이 더 잘 발생하게 될 것이다. 따라서, TAZ711 합금 은 높은 상온 항복강도를 가짐에도 불구하고, 조대한 미재 결정된 결정립들로 인해 낮은 고주기 피로 저항성을 가지 게 되는 것으로 사료된다.

\section{4. 결 론}

본 연구에서는 AZ80과 TAZ711 마그네슘 합금 압출재 의 미세조직과 상온 및 고온 인장 특성, 그리고 고주기 피 로 특성에 대하여 조사하여 다음과 같은 결론을 얻었다.

1. $\mathrm{AZ80}$ 합금 압출재는 소재 전체가 완전히 동적 재결 정된 미세조직을 가지는 반면, TAZ711 합금 압출재는 재 결정되지 않는 조대한 결정립과 재결정된 미세한 결정립이 혼재되어 있다. 반면, AZ80 합금에서는 석출물이 띠를 이
루어 분포하고 있는 반면, TAZ711 합금은 석출물이 시편 전반에 걸쳐 균일하게 분포하고 있다.

2. TAZ711 합금이 조대한 미재결정된 결정립을 가지고 있으나, 재결정된 결정립의 크기는 AZ80 합금에 비해 미 세하다. 두 합금 모두 결정립들의 기저면이 압출 방향과 평행하게 배열된 전형적인 마그네슘 압출재 집합조직을 보 이고 있으나, 집합조직의 강도는 TAZ711 합금이 AZ80 합금 더 크다.

3. 상온 인장 시험 결과, TAZ711 합금의 항복강도가 $\mathrm{AZ} 80$ 합금보다 높으며, 이는 미세한 결정립, 강한 집합조 직, 분산된 석출물로 인한 강화 효과 증대로 인한 것으로 판단된다. 그러나, $\mathrm{AZ} 80$ 합금의 우수한 가공경화능으로 인 해 최대인장강도는 두 합금이 거의 유사하며, 연신율은 항 복강도가 낮은 $\mathrm{AZ80}$ 합금이 더 우수하다.

4. 고온 인장 시험 결과, TAZ711 합금이 AZ80 합금보 다 낮은 강도를 보이며, 이는 전위 크리프와 더불어 미세 한 결정립으로 인한 $\mathrm{GBS}$ 과 확산 크리프의 발생이 TAZ711 합금에서 더 용이하게 발생하기 때문이다. 두 합 금 모두 변형률 속도가 감소함에 따라 강도가 감소하였으 나, 미세한 결정립을 가지는 TAZ711 합금이 변형률 속도 민감도가 높아서 강도 저하가 크게 발생한다.

5. 상온 고주기 피로 시험 결과, 모든 시편이 표면에서 피로균열이 발생하였으며, TAZ711 합금의 상온 항복강도 가 AZ80 합금 보다 높음에도 불구하고 낮은 고주기 피로 특성을 나타낸다. 이는 TAZ711 합금에 존재하는 조대한 결정립들에서 반복 하중 중에 쌍정이 형성되고 쌍정 내에 전위가 축적되어 피로균열이 발생하여 피로 저항성이 감소 한 것으로 사료된다.

\section{감사의 글}

이 논문은 2018년도 정부(미래창조과학부)의 재원으로 한 국연구재단 기초연구실지원사업의 지원을 받아 수행된 연 구임 (No. 2017R1A4A1015628).

\section{REFERENCES}

1. B. L. Mordike and T. Ebert, Mater. Sci. Eng. A 302, 37 (2001).

2. H. Friedrich and S. Schumann, J. Mater. Process. Tech. 117, 276 (2001).

3. S. Ramakrishnan and P. Koltun, Resour. Conserv. Recy. 42, 49 (2004). 
4. Z. B. Sajuri, Y. Miyashita, Y. Hosokai, and Y. Mutoh, Int. J. Mech. Sci. 48, 198 (2006).

5. C. Bettles and M. Barnett, Advances in Wrought Magnesium Alloys: Fundamentals of Processing, Woodhead Publishing, Philadelphia (2012).

6. F. H. Froes, D. Eliezer, and E. Aghion, JOM 50, 30 (1998).

7. S. H. Park, D. H. Cho, K. M. Cho, and I. M. Park, Met. Mater. Int. 24, 1162 (2018).

8. S. W. Nam, Korean J. Met. Mater. 55, 213 (2017).

9. C. J. Bettles and M. A. Gibson, JOM 57, 46 (2005).

10. C. Davies and M. Barnett, JOM 56, 22 (2004).

11. S. Meng, H. Yu, H. Zhang, H. Cui, S. H. Park, W. Zhao, and B. S. You, Mater. Sci. Eng. A 690, 80 (2017).

12. W. J. Kim and T. Y. Kwak, Met. Mater. Int. 23, 660 (2017).

13. G. Yuan, Y. Liu, C. Lu, and W. Ding, Mater. Sci. Eng. A 472, 75 (2008).

14. X. Tan, W. Chee, J. Chan, R. Kwok, and M. Gupta, Met. Mater. Int. 23, 699 (2017).

15. T. T. Sasaki, K. Yamamoto, Y. Honma, S. Kamado, and K. Hono, Scr. Mater. 59, 1111 (2008).

16. H. Yu, Y. M. Kim, B. S. You, H. S. Yu, and S. H. Park, Mater. Sci. Eng. A 559, 798 (2013).

17. S. H. Park and B. S. You, J. Alloy. Compd. 637, 332 (2015).

18. H. Liu, Y. Chen, Y. Tang, S. Wei, and G. Niu, J. Alloy. Compd. 440, 122 (2007).

19. F. R. Elsayed, T. T. Sasaki, C. L. Mendis, T. Ohkubo, and K. Hono, Scr. Mater. 68, 797 (2013).

20. S. H. Park, S. H. Kim, H. S. Kim, J. Yoon, and B. S. You, J. Alloy. Compd. 667, 170 (2016)

21. S. H. Park, H. S. Kim, and B. S. You, Korean J. Met. Mater. 51, 637 (2013).

22. S. S. Park, W. N. Tang, and B. S. You, Mater. Lett. 64, 31 (2010).

23. A. A. Luo, Int. Mater. Rev. 49, 13 (2004).

24. G. E. Dieter, Mechanical Metallurgy, SI Metric Edition, McGraw-Hill Book Company, London (1988).
25. S. H. Kim, J. U. Lee, Y. J. Kim, J. O. Choi, J. H. Lee, and S. H. Park, Korean J. Met. Mater. 56, 40 (2018).

26. M. Shahzad and L. Wagner, Mater. Sci. Eng. A 506, 141 (2009).

27. G. H. Grosch and K.-J. Range, J. Alloy. Compd. 235, 250 (1996).

28. N. Hort, Y. Huang, and K. U. Kainer, Adv. Eng. Mater. 8, 235 (2006).

29. P. S. Roodposhti, A. Sarkar, K. L. Murty, H. Brody, and R. Scattergood, Mater. Sci. Eng. A 669, 171 (2016).

30. H. Somekawa, K. Hirai, H. Watanabe, Y. Takigawa, and K. Higashi, Mater. Sci. Eng. A 407, 53 (2005).

31. J. Koike, R. Ohyama, T. Kobayashi, M. Suzuki, and K. Maruyama, Mater. Trans. 44, 445 (2003).

32. M. G. Zelin, H. S. Yang, R. Z. Valiev, and A. K. Mukherjee, Metall. Trans. A 23, 3135 (1992).

33. S. Suresh, Fatigue of Materials, 2nd ed., Cambridge University Press, Cambridge (1998).

34. A. Styczynski, Ch. Hartig, J. Bohlen, and D. Letzig, Scr. Mater. 50, 943 (2004).

35. C. S. Roberts, Magnesium and Its Alooys, Jhon Wiley and Sons, New York (1960).

36. L. Wu, A. Jain, D. W. Brown, G. M. Stoica, S. R. Agnew, B. Clausen, D. E. Fielden, and P. K. Liaw, Acta Mater. 56, 688 (2008).

37. S. R. Agnew and O. Duygulu, Int. J. Plasticity 21, 1161 (2005).

38. F. Yang, S. M. Yin, S. X. Li, and Z. F. Zhang, Mater. Sci. Eng. A 491, 131 (2008).

39. J. Koike, N. Fujiyama, D. Ando, and Y. Sutou, Scr. Mater. 63, 747 (2010).

40. J. W. Christian and S. Mahajan, Prog. Mater. Sci. 39, 1 (1995).

41. M. R. Barnett, Z. Keshavarz, A. G. Beer, and D. Atwell, Acta Mater. 52, 5093 (2004). 